\title{
Relative humidity, temperature, substrate type, and height of terrestrial lichens in a tropical paramo
}

\author{
Julián Monge-Nájera \\ Laboratorio de Ecología Urbana, Vicerrectoría de Investigación, Universidad Estatal a Distancia (UNED), 2050 San José, \\ Costa Rica; julianmonge@gmail.com
}

Received 07-VII-2018. C Corrected 28-XI-2018. Accepted 28-I-2019.

\begin{abstract}
Lichens are traditionally divided into types such as "crustose", "foliose" and "fruticose", with different shapes and heights. Substrate, temperature and water are thought to affect lichen height, but there are few studies regarding tropical paramo lichens. Along 2015 I measured those variables in the terricolous lichens of the Cerro Buena Vista, paramo (Costa Rica, $9^{\circ} 33^{\prime} \mathrm{N} \& 83^{\circ} 45^{\prime} \mathrm{W}$ ). The measurements were taken inside the lichens and in the substrate under them, in 61 randomly located quadrats $(50 \times 50 \mathrm{~cm})$. Lichens grew taller on (1) warmer ground, (2) wetter ground, (3) the moister Caribbean slope, and (4) the season with heavier rainfall, as expected. Apparently, atmospheric factors are more important than substrate in the determination of temperature, relative humidity and growth of lichens. Physiologically available water seems to be the main determinant of lichen vertical growth in the Buena Vista paramo.
\end{abstract}

Key words: physical variables; growth factors; climate; highland lichens; paramo; thallus growth.

Monge-Nájera, J. (2019). Relative humidity, temperature, substrate type, and height of terrestrial lichens in a tropical paramo. Revista de Biología Tropical, 67(1), 206-212.

How tall can terricolous lichens grow? What determines that growth? Research to answer these two simple questions is not abundant, perhaps because lichens have traditionally been divided into "crustose", "foliose" and "fruticose" growth forms according to their shape and height, a practice that artificially hides a growth continuum (Grube \& Hawksworth, 2007; Tehler \& Irestedt, 2007).

But even though we need to go beyond growth forms to better identify growth factors, it must be borne in mind that they are useful ecological concepts when researchers want to generalize and predict: for example, crustose lichens can colonize more extreme habitats (Rogers, 1990) while foliose and fruticose species are better competitors in less demanding environments (Armstrong, 1993; Armstrong \&
Welch, 2007). In tropical latitudes, the lower temperatures and higher photosynthetic rates of mid altitudes favor foliose and fruticose species (Ceron \& Quintero, 2009), but only crustose species can grow in the more demanding conditions of high altitudes (Rai, Khare, Baniya, Upreti, \& Gupta, 2015). Also in the tropics, crustose lichens are more abundant in primary forests; while fruticose and foliose species are most abundant in disturbed forest, thanks to their endobionts, structure and physiology (Benítez, Aragón, González, \& Prieto, 2018).

According to Rogers (2006), a possible key factor in how tall lichens can grow is the amount of rain. However, the relationship between lichens and water goes beyond rain levels and, in some lichens, incorporates fog, dew and atmospheric water that interact with 
temperature and light to define carbon fixation and thallus growth (Gauslaa, 2014; Colesie, Williams, \& Büdel, 2017).

Paramos are highland tropical environments where low temperatures prevent tree growth, superficially resembling higher latitudes (Kappelle \& Horn, 2005; 2016). The Costa Rican paramo has over 200 described species of lichens but there are few studies about them (Sipman, 2005). Here I compare lichen height, relative humidity, and temperature, in the two slopes of a Costa Rican paramo.

\section{MATERIALS AND METHODS}

The study was done from February through December of 2005 in a site with two slopes, one oriented to the Pacific, the other to the Caribbean, in Cerro Buena Vista (better known as Cerro de la Muerte), Costa Rica. The slopes are at $9^{\circ} 33^{\prime} 33.62^{\prime \prime} \mathrm{N} \& 83^{\circ} 45^{\prime} 20.78^{\prime \prime} \mathrm{W}$ (Pacific) and at 9 $9^{\circ} 4^{\prime} 40.83^{\prime \prime} \mathrm{N} \& 83^{\circ} 45^{\prime} 6.78^{\prime \prime}$ W (Caribbean).

A $200 \mathrm{~m}$ transect, marked at $1 \mathrm{~m}$ intervals, was set with rope on each slope and a digital random number generator (random.org) chose the points where polyvinyl chloride plastic frame markers $(50 \times 50 \mathrm{~cm})$ were placed, as recommended by Root \& McCune (2012) for the study of small scale factors in lichens. There were 30 frames in the Caribbean slope and 31 frames in the Pacific slope; and frames were not moved during the study period, so they were fixed sampling points where measurements were repeated on every trip.

Photographs of frames, and the lichens inside them, are freely available for corroboration: https://doi.org/10.5281/zenodo.1296967. All raw data can also be downloaded for critical review and reanalysis: https://doi.org/10.5281/ zenodo.1296956.

On each visit, I inserted a dual probe (temperature and relative humidity) inside the largest lichen thallus from each plastic frame, and, a couple seconds later, under its thallus, touching the substrate. These single-time records were fed to an electronic datalogger (HOBO U-Shuttle, ONSET, Model: U-DT-1).
I also measured lichen height over ground with a ruler and recorded the substrate type (soil or rock) on each visit. When time permitted, I measured one or two additional lichens per frame, for a larger sample. Measurements were made consistently between all sampling months, between 09:00 $\mathrm{h}$ and 15:00 $\mathrm{h}$ in all visits. The number of dual lichen/soil measurements of temperature and relative humidity (i.e. 4 data for measurement), for February, April, August, October and December (2015) were, respectively, 34, 33, 51, 51 and 51 datasets for the Caribbean; and 31, 33, 43, 44 and 44 datasets for the Pacific slope (for tabulated details, see https://doi.org/10.5281/zenodo.1296956).

\section{Hypotheses}

1. Lichens on hard ground grow shorter because conditions are more difficult (as proposed by Clair, Johansen, \& Rushforth, 1993).

2. Lichens on warmer ground grow taller because of faster physiological reactions (as proposed by Benedict, 1990).

3. Lichens on wetter ground grow taller (as proposed by Rogers, 2006).

4. Caribbean slope lichens grow higher than Pacific slope lichens because they have more water (see Herrera, 1985 for Pacific versus Caribbean climate).

5. Lichens grow taller on the rainy season because of higher levels of available water (Herrera, 1985; Rogers, 2006).

\section{RESULTS}

The substrate was soft (i.e. dirt and organic matter) in 360 measurements and hard (i.e. rock) only in 33 measurements; there were no statistical differences in relative humidity, temperature, or lichen height, between soft and hard soil (Kruskal-Wallis test, $\mathrm{P}>0.05$ for all combinations of variables).

Crustose lichens in the studied area grew less than a millimeter and their height cannot be measured with a ruler, but the mean height of foliose lichens was $15 \mathrm{~mm}$ (Standard Error 
$1.0 \mathrm{~mm}$ ), and for fruticose it was $82 \mathrm{~mm}$ (Standard Error $7.0 \mathrm{~mm}$ ).

There were 139 measurements in which the lichen was fruticose, 123 where it was crustose and 107 where it was foliose, i.e. none of the growth forms dominated numerically the random quadrats $\left(\chi^{2}=4.16, \mathrm{P}=0.1249\right)$.

There were 13 identifiable species in the Caribbean slope and 11 identifiable species in the Pacific slope (Table 1).

In the next sections, figures are presented only when there were statistically significant patterns.

Seasonal Pattern: From December to February there were higher temperatures in both soil and lichens, and a reduction in the mean height of the lichen colonies (KruskalWallis ANOVA, $\mathrm{P}>0.05$; Fig. 1).

From April through October, the soil and the lichens were moister and cooler; and lichen colonies were taller (Fig. 1).
Effect of slope: There were no significant slope differences in temperature, but there was an important difference in relative humidity. In the Caribbean slope, which was wetter, both soil and lichens were moister, and lichens were almost twice as tall as in the Pacific slope of the site (Kruskal-Wallis, $\mathrm{P}<0.001$ in all cases; Fig. 2).

Growth form: Ground temperature and relative humidity were similar to those of the crustose lichens growing on it; but were cooler and moister under foliose and fruticose lichens (Fig. 3).

\section{DISCUSSION}

The lichenoflora of the Costa Rican paramos, has about 200 described species and are dominated by foliose and fruticose forms (Sipman, 2005). The species have wide geographic ranges that include many of the neotropical

TABLE 1

Lichen species versus slope where they were present

\begin{tabular}{|c|c|c|c|}
\hline Species & Morphotype & Caribbean & Pacific \\
\hline Cladia aggregata (Sw.) Spreng. (?) & Fruticose & $\checkmark$ & $\checkmark$ \\
\hline Cladonia andesita* Hedwigia Beiblätter (1899) & Fruticose & $\checkmark$ & \\
\hline Cladonia coccifera* $(\mathrm{L}$.$) Willd (1787)$ & Fruticose & & $\checkmark$ \\
\hline Cladonia confusa* Sant (1942) & Fruticose & $\checkmark$ & $\checkmark$ \\
\hline Cladonia didyma* (Fée) Vain (1887) & Fruticose & $\checkmark$ & \\
\hline Cladonia sp.* & Fruticose & $\checkmark$ & $\checkmark$ \\
\hline Cora sp. & Foliose & $\checkmark$ & \\
\hline Dibaeis absoluta (Tuck.) Kalb \& Gierl (1993) & Crustose & $\checkmark$ & $\checkmark$ \\
\hline Diploschistes cinereocaesius (Sw.) Vain (1921) & Crustose & & $\checkmark$ \\
\hline Everniastrum sp. & Fruticose & $\checkmark$ & \\
\hline Hypotrachyna sp. & Foliose & $\checkmark$ & $\checkmark$ \\
\hline Peltigera $\mathrm{sp}$. & Foliose & $\checkmark$ & \\
\hline Siphula pteruloides Nyl (1859) & Fruticose & $\checkmark$ & \\
\hline Stereocaulon cf. ramulosum? Th. Fr. (1857) & Fruticose & & $\checkmark$ \\
\hline Stereocaulon strictum var. explanatum Th. Fr. (1857) & Fruticose & $\checkmark$ & \\
\hline Stereocaulon tomentosum Fr. (1825) & Fruticose & & $\checkmark$ \\
\hline Trapeliopsis sp. & Fruticose & & $\checkmark$ \\
\hline Usnea sp. & Fruticose & $\checkmark$ & $\checkmark$ \\
\hline Unidentified & Not recorded & $\checkmark$ & $\checkmark$ \\
\hline
\end{tabular}

* Cladonia has a dimorphic thallus. 

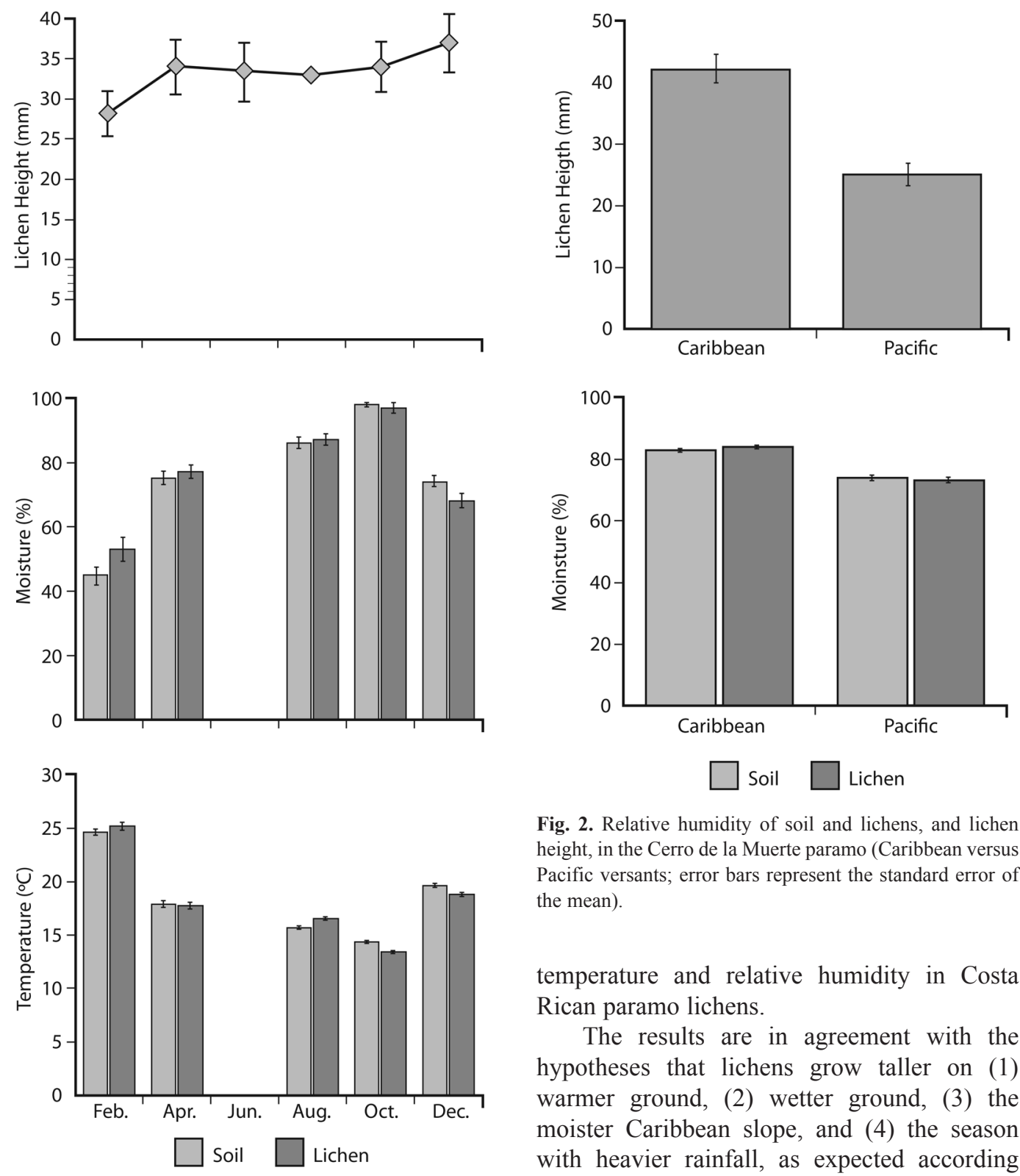

Fig. 1. Yearly trends of mean temperature, relative humidity and lichen height in the Buena Vista paramo. Error bars represent the standard error of the mean (June values are interpolations because there was no sampling in that month, thus they have no error bars).

highlands, possibly as a result of geographic paramo continuity during the Pleistocene (Sipman, 2005; Kappelle \& Horn, 2005; 2016). Apparently this is the first study to analyze

Fig. 2. Relative humidity of soil and lichens, and lichen height, in the Cerro de la Muerte paramo (Caribbean versus Pacific versants; error bars represent the standard error of the mean).

temperature and relative humidity in Costa Rican paramo lichens.

The results are in agreement with the hypotheses that lichens grow taller on (1) warmer ground, (2) wetter ground, (3) the moister Caribbean slope, and (4) the season with heavier rainfall, as expected according to the findings of, among others, Benedict (1990), and Rogers (2006). Benedict's experiments with Xanthoparmelia spp. showed that warmer temperatures, and increased moisture available for photosynthesis, correlated with a positive net carbon assimilation rate that was rapidly translated into lobe elongation (Benedict, 1990). Rogers' study of 61 Australian lichen species along a $1500 \mathrm{~km}$ transect found that taller species dominated wetter regions 

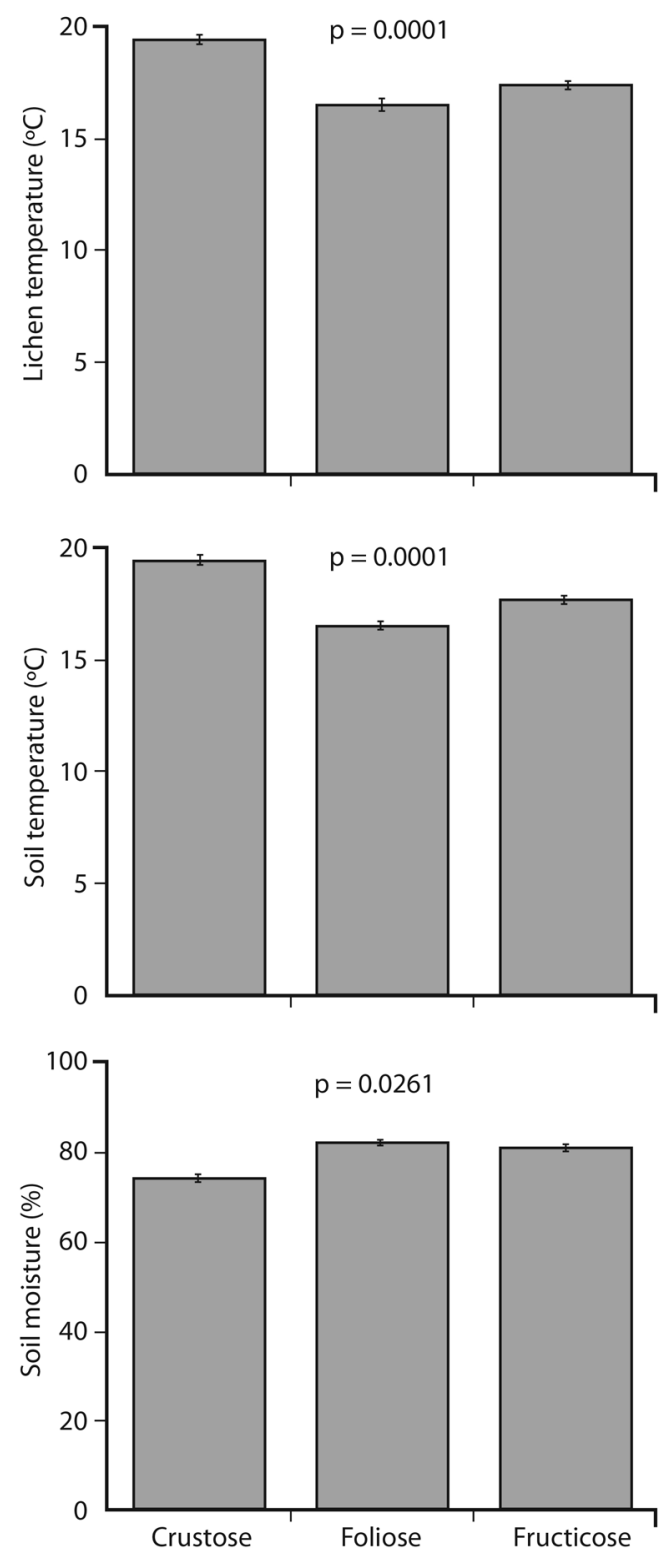

Fig. 3. Temperature (soil and lichens) and soil relative humidity for each lichen growth form, in the Cerro de la Muerte paramo (Caribbean versus Pacific versants; error bars represent the standard error of the mean; $p$ values indicate that bars of different height represent significantly different mean values for those variables). and shorter species dominated the dry interior (Rogers, 2006).

The data did not match one hypothesis, though: in contrast with softer ground, rockhard substrates fluctuate abruptly in temperature and do not absorb water well (Clair et al., 1993; Giordani et al., 2014), so I expected less vertical growth in lichens growing on rock. Apparently from these results, atmospheric factors are more important than substrate in the determination of temperature, relative humidity and growth of lichens. Some temperate and tropical lichens can use water from dew, fog or humid air for growth that exceeds what may be expected from substrate alone (Lange, Green, \& Heber, 2001; Lange, Buedel, Meyer, Zellner, \& Gerhard, 2004; Lange, Green, Melzer, Meyer, $\&$ Zellner, 2006) but only future research could identify with certainty the cause of these results for the Costa Rican paramo lichens.

The finding that crustose species, which do not raise much from the ground, basically have the same temperature and relative humidity as the substrate, is not surprising. There are no equivalent tropical data that I know of, but Cao, Zhang, Zheng, Liu, and Zhou (2015) reported similar results in Antarctic lichens: species with a tufted thallus were better protected from external conditions than those with low lying thalli. And the classic studies by Kershaw and colleagues in Canada found that tall lichens have thermic and moisture gradients, from the top layer, which closely matches environmental fluctuations, to the lower levels, where conditions are milder and moisture is often high, and the taller the lichen, the larger the gradient (Kershaw, \& Field, 1975; Kershaw, \& Smith, 1978).

Overall, these findings suggests that physiologically available water is the main determinant of lichen vertical growth in the Buena Vista paramo. Based on these and other findings from lichens in Buena Vista and elsewhere 
(Mehlen, 1969; Bässler et al., 2015; Bokhorst, Asplund, Kardol, \& Wardle, 2015; Maestre et al., 2015), I recommend future work on the hypothesis that taller and more tufted lichens -and their microcommunities- will be more resistant to climate change than those with flat, low growth thalli.

Ethical statement: authors declare that they all agree with this publication and made significant contributions; that there is no conflict of interest of any kind; and that we followed all pertinent ethical and legal procedures and requirements. A signed document has been filed in the journal archives.

\section{ACKNOWLEDGMENTS}

The comments of five anonymous reviewers were useful to improve this report. I thank Maribel Zúñiga, Frank González and Sergio Quesada for their valuable field work, and Zaidett Barrientos for financial and logistical support and for useful comments to improve the manuscript. Carolina Seas, Sergio Aguilar and Ligia Bermúdez helped greatly with data analysis and figures. I also thank the Servicio de Parques Nacionales for the research permit and for supporting this study. The project was financed by Vicerrectoría de Investigación UNED de Costa Rica (Project 2013-0019: Páramos neotropicales: amenazas al ecosistema por cambio global; http:/gestiona.uned. ac.cr). Harrie J.M. Sipman (Botanischer Garten und Botanisches Museum, Berlin) identified the lichens and gave valuable suggestions.

\section{RESUMEN}

Humedad relativa, temperatura, tipo de sustrato y altura de los líquenes del suelo en un páramo tropical. Los líquenes se dividen tradicionalmente en morfotipos como "crustoso", "folioso" y "fruticoso", con diferentes formas y alturas. Se cree que el sustrato, la temperatura y el agua afectan la altura de los líquenes, pero existen pocos estudios con respecto a los líquenes tropicales. A lo largo del 2015, medí esas variables en los líquenes del suelo en el páramo de Cerro Buena Vista (Costa Rica, $9^{\circ} 33^{\prime} \mathrm{N}$; 83 $\left.{ }^{\circ} 45^{\prime} \mathrm{W}\right)$. Las medidas se tomaron dentro de los líquenes y en el sustrato debajo de ellos, en 61 cuadrantes ubicados al azar $(50 \times 50 \mathrm{~cm})$. Los líquenes fueron más altos en (1) suelo más cálido, (2) suelo más húmedo, (3) la pendiente del Caribe, que es más húmeda y (4) la temporada con lluvias más intensas, como se esperaba. Aparentemente, los factores atmosféricos son más importantes que el sustrato en la determinación de la temperatura, la humedad relativa y el crecimiento de los líquenes. El agua fisiológicamente disponible parece ser el principal determinante del crecimiento vertical de los líquenes en el páramo del Cerro Buena Vista.

Palabras clave: variables físicas; tasa de crecimiento; clima; líquenes de tierras altas; páramo.

\section{REFERENCES}

Armstrong, R. A. (1993). Factors determining lobe growth in foliose lichen thalli. New Phytologist, 124(4), 675679. DOI: 10.1111/j.1469-8137.1993.tb03857.x

Armstrong, R. A., \& Welch, A. R. (2007). Competition in lichen communities. Symbiosis, 43(1), 1-12.

Bässler, C., Cadotte, M. W., Beudert, B., Heibl, C., Blaschke, M., Bradtka, J. H., ... Müller, J. (2015). Contrasting patterns of lichen functional diversity and species richness across an elevation gradient. Ecography, 39(7), 689-698. DOI:10.1111/ecog.01789

Benedict, J. B. (1990). Experiments on lichen growth. I. Seasonal patterns and environmental controls. Arctic and Alpine Research, 22(3), 244-254. DOI: $10.2307 / 1551587$

Benítez, A., Aragón, G., González, Y., \& Prieto, M. (2018). Functional traits of epiphytic lichens in response to forest disturbance and as predictors of total richness and diversity. Ecological Indicators, 86, 18-26.

Bokhorst, S., Asplund, J., Kardol, P., \& Wardle, D. A. (2015). Lichen physiological traits and growth forms affect communities of associated invertebrates. Ecology, 96(9), 2394-2407. DOI: 10.1890/14-1030.1

Cao, S., Zhang, J., Zheng, H., Liu, C., \& Zhou, Q. (2015). Photosynthetic performance in Antarctic lichens with different growth forms reflect the diversity of lichenized algal adaptation to microhabitats. Polish Polar Research, 36(2), 175-188. DOI: 10.1515/ popore-2015-0012

Ceron, B. W., \& Quintero, A. L. P. (2009). Estructura de una comunidad de líquenes y morfología del género Sticta (Stictaceae) en un gradiente altitudinal. Acta Biológica Colombiana, 14(3), 157.

Clair, L. L. St., Johansen, J. R., \& Rushforth, S. R. (1993). Lichens of soil crust communities in the intermountain area of the western United States. The Great Basin Naturalist, 53(1), 5-12. 
Colesie, C., Williams, L., \& Büdel, B. (2017). Water relations in the soil crust lichen Psora decipiens are optimized via anatomical variability. The Lichenologist, 49(5), 483-492.

Gauslaa, Y. (2014). Rain, dew, and humid air as drivers of morphology, function and spatial distribution in epiphytic lichens. The Lichenologist, 46(01), 1-16. DOI: $10.1017 / \mathrm{S} 0024282913000753$

Giordani, P., Incerti, G., Rizzi, G., Rellini, I., Nimis, P. L., \& Modenesi, P. (2014). Functional traits of cryptogams in Mediterranean ecosystems are driven by water, light and substrate interactions. Journal of Vegetation Science, 25(3), 778-792. DOI: 10.1111/ jvs.12119

Grube, M., \& Hawksworth, D. L. (2007). Trouble with lichen: the re-evaluation and re-interpretation of thallus form and fruit body types in the molecular era. Mycological Research, 111(9), 1116-1132. DOI: 10.1016/j.mycres.2007.04.008

Herrera, W. (1985). Clima de Costa Rica. San José, Costa Rica: Editorial de la Universidad Estatal a Distancia.

Kappelle, M., \& Horn, S. P. (2005). Páramos de Costa Rica. Heredia, Costa Rica: Editorial INBio.

Kappelle, M., \& Horn, S. (2016). The Paramo Ecosystem of Costa Rica's Highlands. In M. Kappelle (Ed.), Costa Rican Ecosystems (pp. 492-525). Chicago, USA: University of Chicago Press. DOI: 10.7208/ chicago/9780226121642.001.0001

Kershaw, K. A., \& Field, G. F. (1975). Studies on lichendominated systems. XV. The temperature and humidity profiles in a Cladina alpestris mat. Canadian Journal of Botany, 53(22), 2614-2620.

Kershaw, K. A., \& Smith, M. M. (1978). Studies on lichendominated systems. XXI. The control of seasonal rates of net photosynthesis by moisture, light, and temperature in Stereocaulon paschale. Canadian Journal of Botany, 56(22), 2825-2830.

Lange, O. L., Green, T. A., \& Heber, U. (2001). Hydration-dependent photosynthetic production of lichens: what do laboratory studies tell us about field performance? Journal of Experimental Botany, 52(363), 2033-2042.

Lange, O. L., Buedel, B., Meyer, A., Zellner, H., \& Gerhard, Z. O. T. Z. (2004). Lichen carbon gain under tropical conditions: water relations and $\mathrm{CO}_{2}$ exchange of Lobariaceae species of a lower montane rainforest in Panama. The Lichenologist, 36(5), 329-342.

Lange, O. L., Green, T. A., Melzer, B., Meyer, A., \& Zellner, H. (2006). Water relations and $\mathrm{CO}_{2}$ exchange of the terrestrial lichen Teloschistes capensis in the Namib fog desert: measurements during two seasons in the field and under controlled conditions. FloraMorphology, Distribution, Functional Ecology of Plants, 201(4), 268-280.

Maestre, F. T., Escolar, C., Bardgett, R. D., Dungait, J. A., Gozalo, B., \& Ochoa, V. (2015). Warming reduces the cover and diversity of biocrust-forming mosses and lichens, and increases the physiological stress of soil microbial communities in a semi-arid Pinus halepensis plantation. Frontiers in Microbiology, 6, 865. DOI: $10.3389 /$ fmicb. 2015.00865

Mehlen, R. H. (1969). Tardigrada: taxonomy and distribution in Costa Rica. Transactions of the American Microscopical Society, 498-505. DOI: $10.2307 / 3224244$

Rai, H., Khare, R., Baniya, C. B., Upreti, D. K., \& Gupta, R. K. (2015). Elevational gradients of terricolous lichen species richness in the Western Himalaya. Biodiversity and Conservation, 24(5), 1155-1174. DOI: 10.1007/s10531-014-0848-6

Rogers, R. W. (1990). Ecological strategies of lichens. The Lichenologist, 22(02), 149-162. DOI: 10.1017/ S002428299000010X

Rogers, R. W. (2006). Soil surface lichens on a 1500 kilometre climatic gradient in subtropical eastern Australia. The Lichenologist, 38(6), 565-576. DOI: 10.1017/ S0024282906006098

Root, H. T., \& McCune, B. (2012). Surveying for biotic soil crust lichens of shrub steppe habitats in the Columbia Basin. North American Fungi, 7, 1-21. DOI: 10.2509/ naf2012.007.007

Sipman, H. J. M. (2005). Páramos de Costa Rica. In M. Kappelle, \& S. P. Horn (Eds.), Páramos de Costa Rica (pp. 343-360). Heredia, Costa Rica: Editorial INBio.

Tehler, A., \& Irestedt, M. (2007). Parallel evolution of lichen growth forms in the family Roccellaceae (Arthoniales, Ascomycota). Cladistics, 23(5), 432454. DOI: 10.1111/j.1096-0031.2007.00156.x 